\title{
Species - specific PCR test for the quick recognition of equine tissue in raw and processed beef meat mixtures
}

\author{
Khaled Abd El-Hamid ABD EL-RAZIK ${ }^{1 *}$, Azza Sayed Mohamed ABUELNAGA², Abdelgayed Metwaly YOUNES ${ }^{3}$, \\ Nagwa Sayed ATTA², Amany Ahmed ARAFA², Mai Mohamed KANDIL ${ }^{2}$
}

\begin{abstract}
PCR was applied for the discovery of adulteration of crude and processed beef meat with horse and donkey tissue. This was performed by blending $(\mathrm{w} / \mathrm{w})$ horse or donkey meat to beef meat in an extent up to 1:10000 (0.01\%). The sensitivity was resolved as high as $0.01 \%$. All used primers showed specificity in the PCR reactions utilizing layout DNAs from three animal species. PCR application on 96 beef meat and meat product samples gathered randomly from street vendors and prominent retail markets (24 of burger, 16 of minced meat, 24 of kofta, 16 of sausage, 7 of raw meat and 9 of launcheon) uncovered 6 positive for donkey tissue ( 3 from sausage, 2 from minced meat and 1 from kofta) and 2 positive for horse tissue (from sausage). This basic PCR strategy effectively distinguished adulteration of raw and processed beef meat samples with horse and donkey tissue. This work also highlights on the severity of the meat adulteration problem in Egypt.
\end{abstract}

Keywords: meat adulteration; Egypt; PCR; beef; equines.

Practical Application: Species-Specific PCR for identification of horse and donkey tissue in raw and processed beef meat to prevent meat adulteration in Egypt.

\section{Introduction}

Regardless of performing more strict food labeling regulations locally and all around, the adulteration or misrepresentation of food products to get highlights on the severity keeps to be a typical element of society (Singh \& Neelam, 2011; Rahmati et al., 2016). Traditionally, meat had not been affected with corruption since meat was sold as fresh, effortlessly unmistakable (Nakyinsige et al., 2012). In many cases, with the rising costs of commercial meat, the globalization of food business and the intense processing of meat into esteem included items, the incidence of meat adulteration and fraud has become more obvious (Vandendriessche, 2008; Meira et al., 2017). Typical cases of intentional meat corruption incorporate the substitution or expansion of animal proteins (typically less expensive ones) such as donkey or horse meat not expressed all things considered in the fixing list) (Flores-Munguia et al., 2000; Wielogorska et al., 2018).

The capability to recognize questionable species in meat items is critical not only for economic, health, moral and religious reasons, but also to guarantee fair trade and commitment with related laws (Nakyinsige et al., 2012; Abbas et al., 2018). Most indicative strategies used to identify meat have relied upon the revealing of species-particular proteins or DNA (Ballin et al., 2009; Hossain et al., 2017). Today, DNA is considered to be the most appropriate particle for species identifying and distinguishing evidence in foods (Singh \& Neelam, 2011). On contrast to proteins, is DNA mostly steady at high temperatures; so it can be analyzed in processed, degraded and mixed supplies (Lenstra, 2003; Meira et al., 2017; Abbas et al., 2018). In addition, while the discovery and identification of proteins rely on the type of the tissue examined, DNA exists and is typical in nearly all cells also the variety given by the hereditary code allows the isolation of even entirely-related species (Lockley \& Bardsley, 2000; Ballin, 2010; Xiang et al., 2017).

DNA-based strategies that have been genuine for species recognizable pieces of proof incorporate DNA hybridization, polymerase chain reaction (PCR), multiplex-PCR, species-specific PCR, restriction-fragment-length-polymorphism (PCR-RFLP) test, real-time PCR and PCR sequencing (Lopez-Andreo et al., 2005; Man et al., 2007; Karlsson \& Holmlund, 2007; Chen et al., 2010; Xiang et al., 2017).

This study assesses a technique for equine tissue identification in meat and meat items in the Egyptian street vendors and retail markets utilizing species- specific PCR. The purpose is to build up a system with outstanding sensitivity and specificity that 
could be utilized as a part of routine control measures to identify undesirable meat species in beef meat products.

\section{Materials and methods}

\subsection{Meat samples}

Muscle tissue samples from beef, donkey and horse were used as positive control samples in addition to meat and meat product samples which had been collected randomly from street vendors and popular retail markets of Giza governorate .Meat samples were stored at $-20^{\circ} \mathrm{C}$ until analyzed.

\subsection{DNA extraction from meats and meat mixtures}

DNA was extracted from meat samples by using GF-1 Tissue DNA Extraction Kit (Cat.no. GF-TD-050, Vivantis Technologies, Malaysia) and following the manual instruction with some modifications, where $50 \mathrm{mg}$ of tissue samples were used and DNA was eluted in 50 $\mu$ l of preheated Elution Buffer provided in the kit.

\subsection{Test meat mixtures}

Meat samples were minced and prepared separately with method modified from Ilhak \& Arslan (2007) by adding (w/w) horse or donkey meat to beef meat samples in a proportion of $9: 10,8: 10,7: 10,6: 10,5: 10,4: 10,3: 10,2: 10,1: 10,1: 100(1 \%)$, $1: 000(0.1 \%), 1: 10000(0.01 \%)$. The mixtures of meat were prepared in a total weight of $250 \mathrm{~g}$. After mixing and fine mincing, a $50 \mathrm{mg}$ portion of each sample had been taken separately and DNA was extracted from each meat sample and used for PCR analysis.

\subsection{Use of PCR for detection of fraud meat in the Egyptian market}

PCR was used to test 96 meat and meat product samples which had been collected randomly from street vendors and popular retail markets of Giza governorate (24 of burger, 16 of minced meat, 24 of kofta, 16 of sausage, 7 of raw meat and 9 of luncheon). The samples stored at $4^{\circ} \mathrm{C}$ then transported to the laboratory and processed immediately.

\subsection{Primer design}

Species specific PCR primers for the amplification of bovine, horse and donkey meat were designed (Table 1). All primers were obtained from Vivantis Technologies, Malaysia.

\subsection{Species-specific Polymerase Chain Reaction (PCR)}

The 50- $\mu$ l reaction mixture was prepared in an Eppendorf tube containing $25 \mu \mathrm{l}$ of $2 \mathrm{X}$ ViRed Taq Master Mix (Cat. no. CLMM01, Vivantis Technologies, Malaysia), 20 pmol of each primer, and $5 \mu$ of target DNA with amplification conditions as described in (Table 2). Electrophoresis was run on 1.5\% agarose gel at $100 \mathrm{~V}$ for $2 \mathrm{~h}$ on a $15-\mu \mathrm{l}$ portion of the amplified DNA products. The resulting gel was stained visualized.

\section{Results}

\subsection{Specificity of the species-specific primers}

Specificity of the species-specific primers and ideal PCR conditions were intended for the identification of beef, donkey, and horse tissues in the meat samples. The primers created species particular products of 145,153 and $271 \mathrm{bp}$ for beef, donkey and

Table 1. The primer pairs used in specific PCR identification of bovine, horse, and donkey meats.

\begin{tabular}{|c|c|c|c|}
\hline Species & Sequence & $\begin{array}{c}\text { PCR } \\
\text { product }\end{array}$ & Reference \\
\hline Bovine & $\begin{array}{l}\text { 5'-GCCATATACTCTCCTTGGTGACA-3' } \\
\text { 5'- GTAGGCTTGGGAATAGTACGA- 3' }\end{array}$ & $271 b p$ & Ilhak \& Arslan (2007) \\
\hline Horse & $\begin{array}{l}\text { 5'-CTATCCGACACACCCAGAAGTAAAG-3' } \\
\text { 5'-GATGCTGGGAAATATGATGATCAGA-3' }\end{array}$ & $153 \mathrm{bp}$ & Kesmen et al. (2010) \\
\hline
\end{tabular}

Table 2. Primer cycling conditions during PCR.

\begin{tabular}{|c|c|c|c|c|c|c|}
\hline Species & $\begin{array}{c}\text { Initial } \\
\text { Denaturation }\end{array}$ & Denaturation & Number of cycles & Annealing & Extension & Final Extension \\
\hline Bovine & $\begin{array}{l}94^{\circ} \mathrm{C}, \\
3 \mathrm{~min}\end{array}$ & $\begin{array}{l}94^{\circ} \mathrm{C}, \\
45 \mathrm{Sec}\end{array}$ & 35 cycles & $\begin{array}{l}58^{\circ} \mathrm{C}, \\
45 \mathrm{Sec}\end{array}$ & $\begin{array}{l}72^{\circ} \mathrm{C}, \\
90 \mathrm{Sec}\end{array}$ & $\begin{array}{l}72^{\circ} \mathrm{C}, \\
5 \mathrm{~min}\end{array}$ \\
\hline Donkey & $\begin{array}{l}94^{\circ} \mathrm{C} \\
3 \mathrm{~min}\end{array}$ & $\begin{array}{l}94^{\circ} \mathrm{C} \\
50 \mathrm{Sec}\end{array}$ & 35 cycles & $\begin{array}{l}57^{\circ} \mathrm{C} \\
50 \mathrm{Sec}\end{array}$ & $\begin{array}{l}72^{\circ} \mathrm{C} \\
1 \mathrm{~min}\end{array}$ & $\begin{array}{l}72^{\circ} \mathrm{C}, \\
5 \mathrm{~min}\end{array}$ \\
\hline Horse & $\begin{array}{l}94^{\circ} \mathrm{C} \\
3 \mathrm{~min}\end{array}$ & $\begin{array}{l}94^{\circ} \mathrm{C}, \\
50 \mathrm{Sec}\end{array}$ & 35 cycles & $\begin{array}{l}61^{\circ} \mathrm{C} \\
50 \mathrm{Sec}\end{array}$ & $\begin{array}{l}72^{\circ} \mathrm{C} \\
1 \mathrm{~min}\end{array}$ & $\begin{array}{l}72^{\circ} \mathrm{C} \\
5 \mathrm{~min}\end{array}$ \\
\hline
\end{tabular}




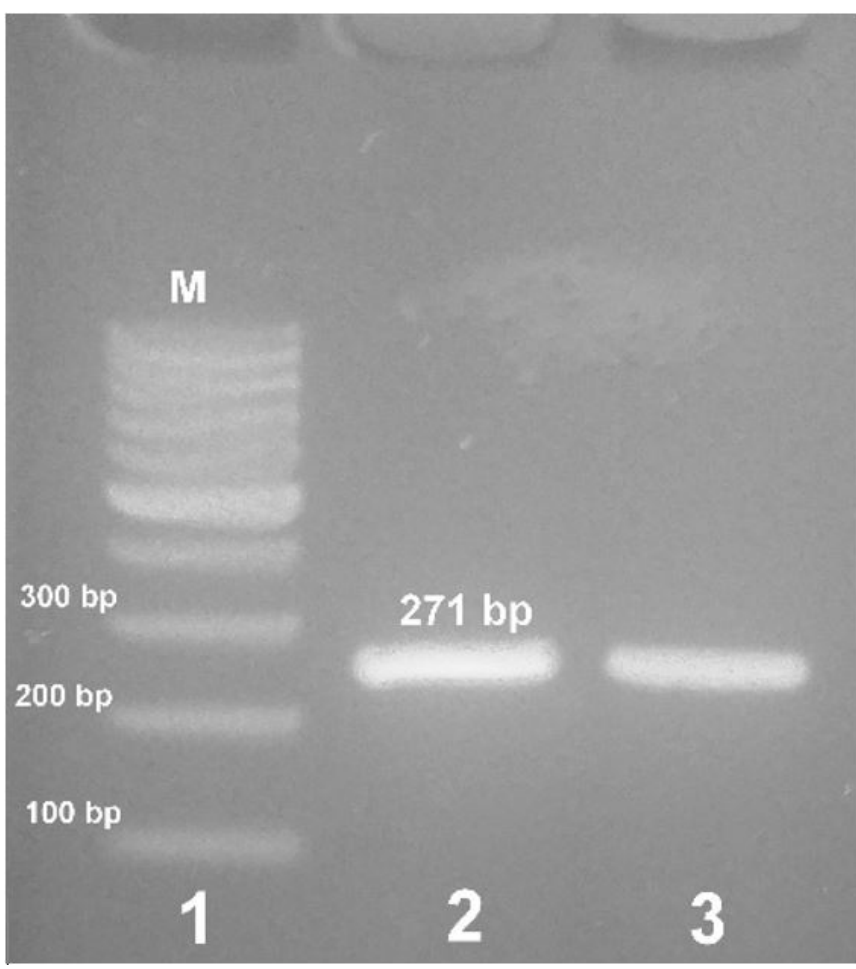

Figure 1. Agarose gel electrophoresis of PCR products amplified from beef meat: lane $1(\mathrm{M}), 100 \mathrm{bp}$ molecular marker; lanes 2\&3, PCR band amplified from beef meat DNA (271bp). M: means molecular marker.

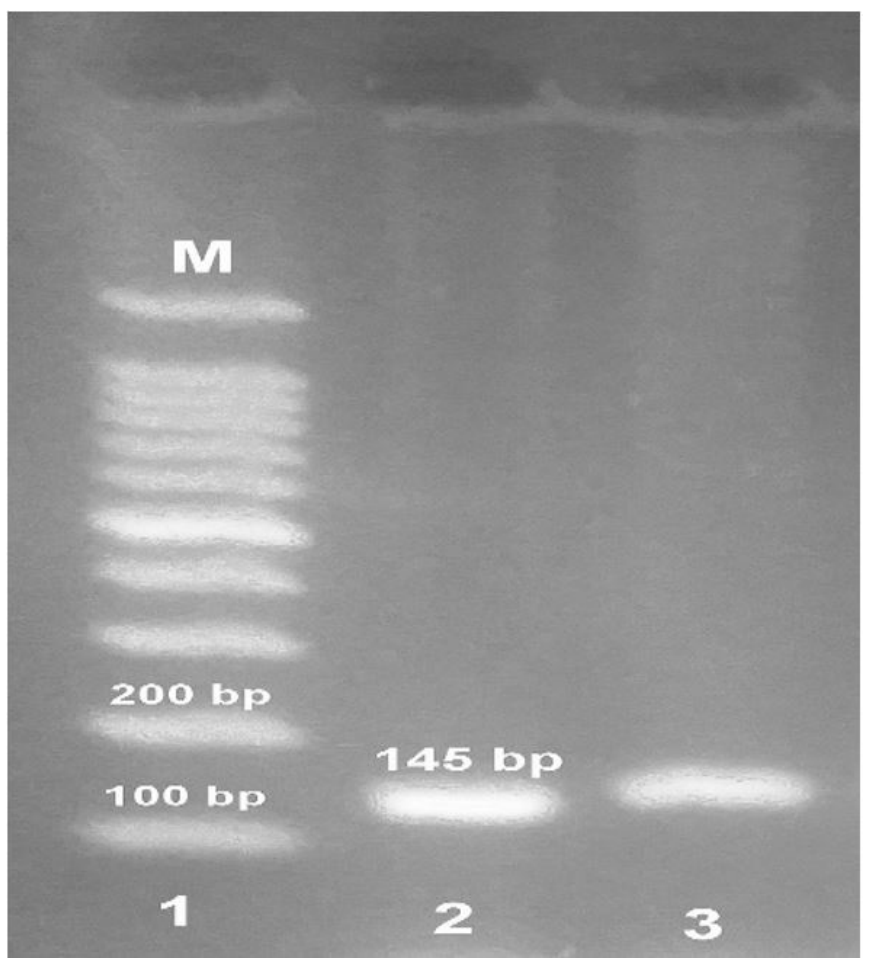

Figure 2. Agarose gel electrophoresis of PCR products amplified from donkey meat: lane 1, 100bp molecular marker; lanes 2\&3, PCR band amplified from donkey meat DNA (145bp). M: means molecular marker. horse tissue, respectively. The specificity of each species- specific primer was ensured by PCR amplification of beef, donkey and horse genomic DNA with each primer set. These yielded PCR products just from the DNA extracted species that they were planned for, and demonstrated no cross-reactivity with the DNA from alternative species (Figure 1, 2, 3). PCR products were not gotten from negative controls with any of the species-specific primer sets.

\subsection{Sensitivity of the species-specific primers}

The detection limits of species-particular PCR examination were identified by amplification of DNA separated from each species by including (w/w) horse or donkey minced meat to beef minced meat samples in an extent of 9:10, 8:10, 7:10, 6:10, 5:10, 4:10, 3:10, 2:10, 1:10, 1:100 (1\%), 1:1000 (0.1\%), 1:10000 $(0.01 \%)$.The observed sensitivity was $1: 10000(0.01 \%)$ for minced beef meat blended by either donkey (Figures 4,5 ) or horse meat (Figures 6,7).

\subsection{Application of species-specific PCR assay to meat products}

Testing 96 meat and meat product samples which had been gathered arbitrarily from street vendors and prominent retail markets of Giza governorate (24 of burger, 16 of minced meat, 24 of kofta, 16 of sausage, 7 of raw meat and 9 of launcheon) revealed that 6 positive for donkey tissue ( 3 from sausage, 2 from minced meat and 1 from kofta) (Figure 8) and 2 positive for horse tissue (from sausage) (Figure 9) as appeared in (Table 3 ). No cross-reaction, again inhibition or unexpected PCR products was detected in the blended tissues.

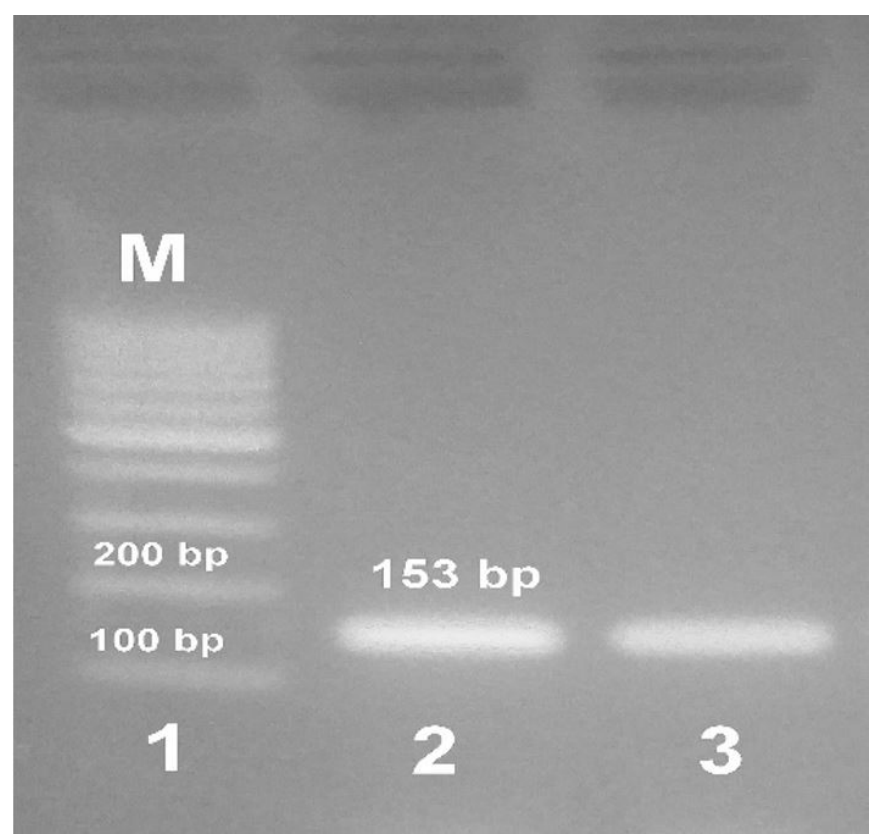

Figure 3. Agarose gel electrophoresis of PCR products amplified from horse meat: lane 1, 100bp molecular marker; lanes $2 \& 3$, PCR band amplified from horse meat DNA (153bp). M: means molecular marker. 


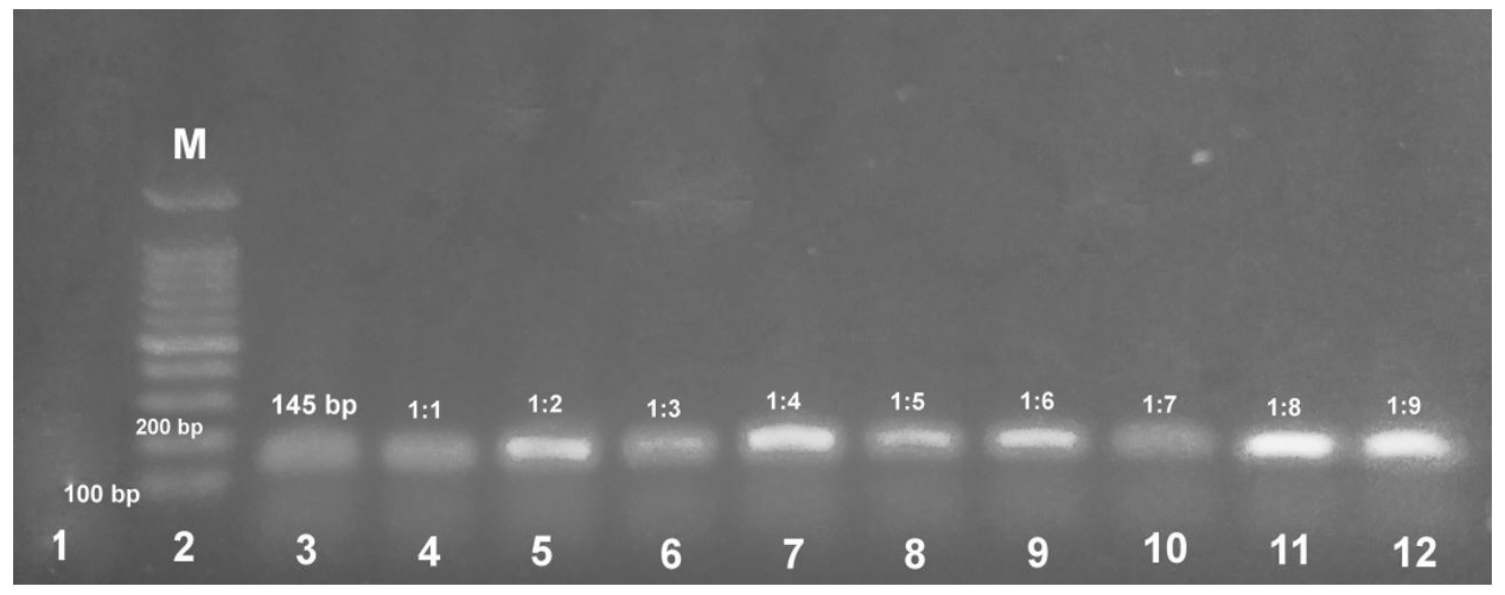

Figure 4. Agarose gel electrophoresis of PCR products amplified from donkey meat: lane 1, PCR band amplified from reaction without template DNA; lane 2, molecular marker, lane 3, PCR from 100\% donkey meat (positive control), lanes 4-12, minced donkey meat diluted with beef meat in a proportion of 1:1, 1:2, 1:3, 1:4, 1:5, 1:6,1:7,1:8 and 1:9 respectively. M: means molecular marker.

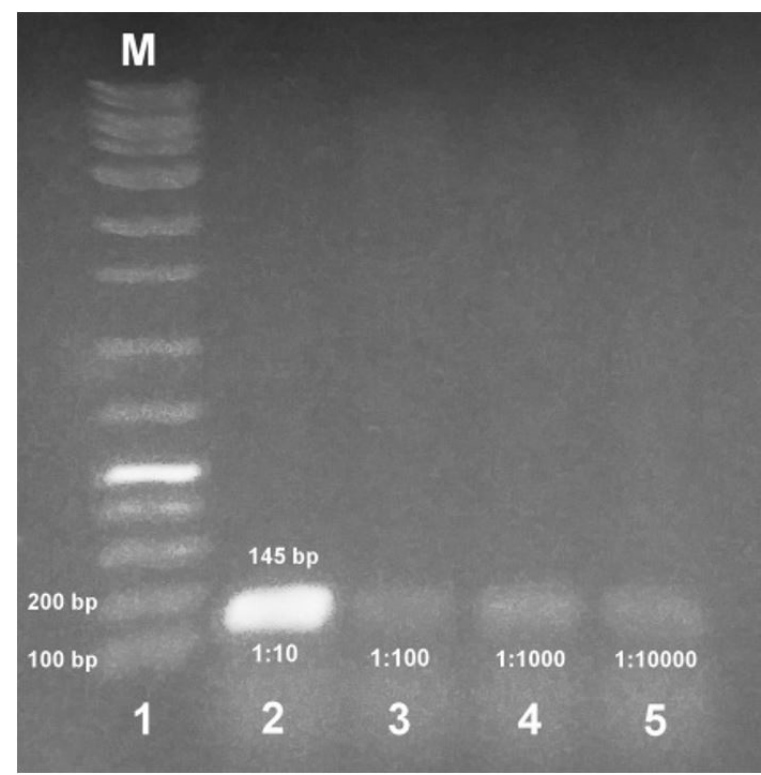

Figure 5. Agarose gel electrophoresis of PCR products amplified from donkey meat: lane 1, molecular marker, lanes 2-5, minced donkey meat diluted with beef meat in a proportion of 1:10, 1:100, 1:1000, 1:10000 respectively. M: means molecular marker.

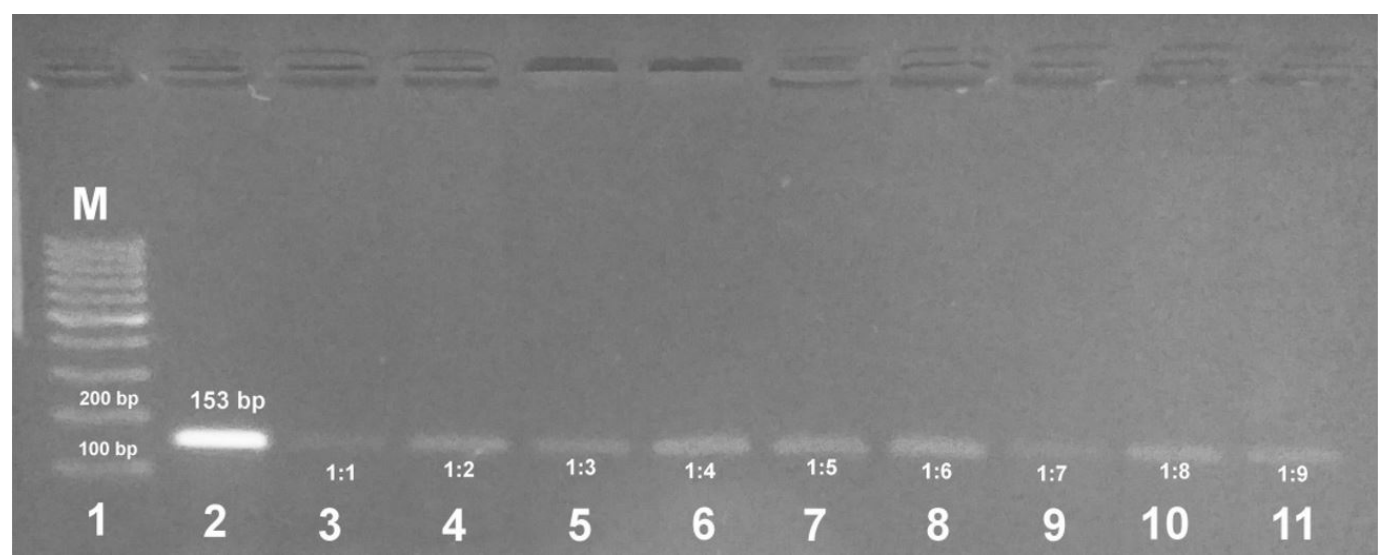

Figure 6. Agarose gel electrophoresis of PCR products amplified from horse meat: lane 1, molecular marker, lane 2, PCR from 100\% horse meat (positive control), lanes 3-11, minced horse meat diluted with beef meat in a proportion of 1:1, 1:2, 1:3, 1:4, 1:5, 1:6,1:7,1:8 and 1:9 respectively. M: means molecular marker. 


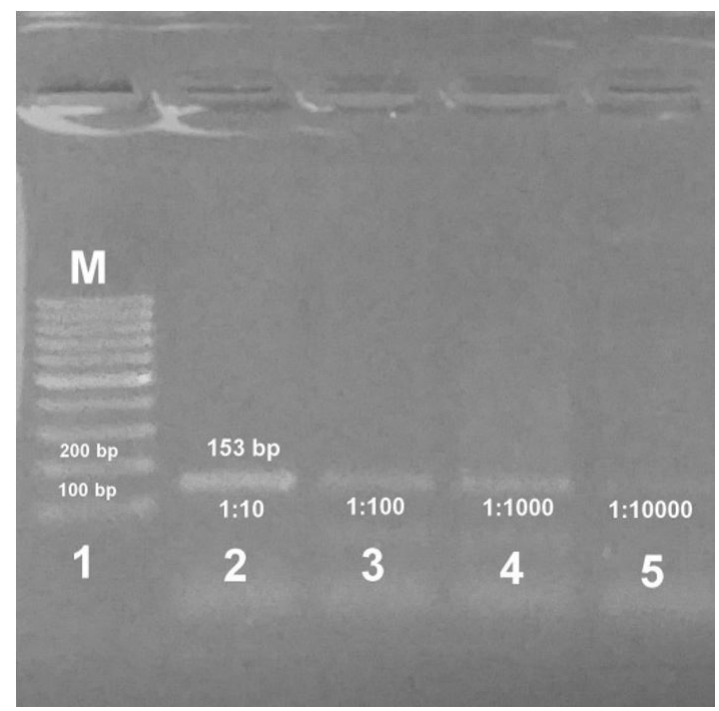

Figure 7. Agarose gel electrophoresis of PCR products amplified from horse meat: lane 1, molecular marker, lanes 2-5, minced horse meat diluted with beef meat in a proportion of 1:10, 1:100, 1:1000, 1:10000 respectively. M: means molecular marker.

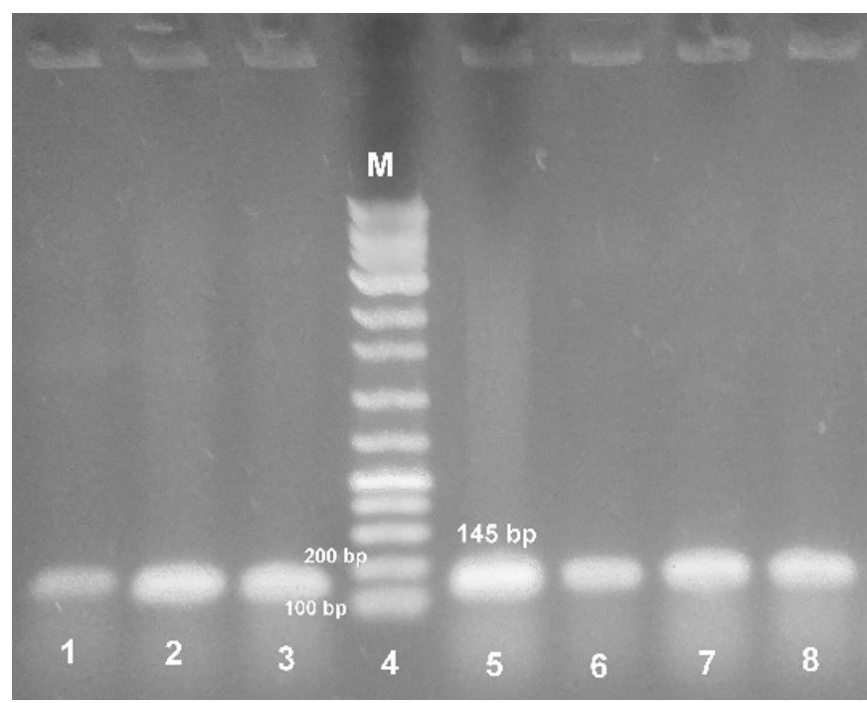

Figure 8. Agarose gel electrophoresis of PCR products amplified from commercial meat products: lane 5, PCR from $100 \%$ donkey meat (positive control); lanes 1-3 \& 6-8, PCR product from market meat products, lane 4, molecular marker. M: means molecular marker.

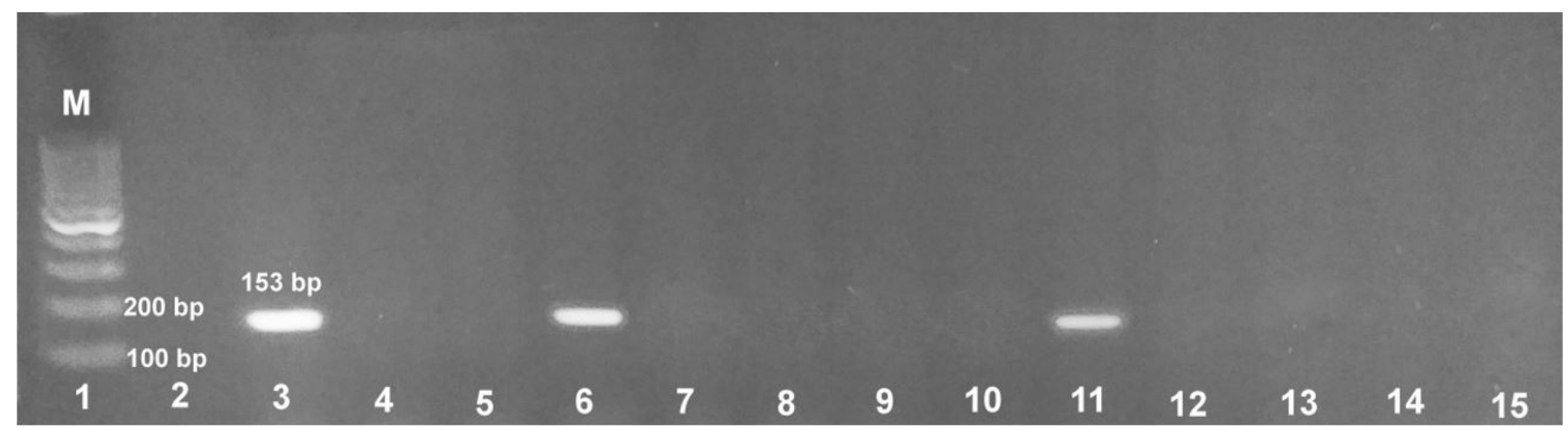

Figure 9. Agarose gel electrophoresis of PCR products amplified from commercial meat products: lane 1, molecular marker; lane 2, negative control, lane 3, PCR from 100\% horse meat (positive control); lanes 6 \& 11, PCR product from market meat products, Lanes 4,5,7-10\&12-15 were negative samples. M: means molecular marker.

Table 3. Number and percentage of adulterated meat samples with donkey and horse meat (total 96 samples).

\begin{tabular}{|c|c|c|c|c|}
\hline \multirow{2}{*}{ Sample } & \multicolumn{2}{|c|}{ Donkey } & \multicolumn{2}{|c|}{ Horse } \\
\hline & No & $\%$ & No & $\%$ \\
\hline Burger & $0 / 24$ & 0 & $0 / 24$ & 0 \\
\hline Minced meat & $2 / 16$ & 12.5 & $0 / 16$ & 0 \\
\hline Kofta & $1 / 24$ & 4.16 & $0 / 24$ & 0 \\
\hline Sausage & $3 / 16$ & 18.75 & $2 / 16$ & 12.5 \\
\hline Raw meat & $0 / 7$ & 0 & $0 / 7$ & 0 \\
\hline Lancheon & $0 / 9$ & 0 & $0 / 9$ & 0 \\
\hline Total & $6 / 96$ & 6.25 & $2 / 96$ & 2.08 \\
\hline
\end{tabular}




\section{Discussion}

Species identification of animal's tissues in meat items is a noteworthy subject to protect consumers against any fraud or corruption for financial, religious and health reasons. The adulteration or misrepresentation of food products for more profit is a common matter all around (Shears, 2010; Doosti et al., 2014; Meira et al., 2017). Substitution with illegally utilized species is so difficult to be identified in such items by visual inspection after grinding and/or heat processing (Abd El-Nasser et al., 2010).

So there are numerous demonstrative techniques which are prepared by depending on protein and DNA investigation (Kesmen et al., 2007; Callao \& Ruisanchez, 2018). Advance in DNA innovation has prompted quick development of alternative approaches for species identification (Mousa et al., 2017).

In this study, the species-particular PCR was created for the identification of donkey and horse species in common beef meat and meat products which had been gathered from street vendors and basic retails markets of Giza governorate with a single PCR reaction step. The primers created particular products of 271,145 and 153bp for beef, donkey and horse tissues, respectively as appeared in Figures 1, 2, 3.

The current extraction technique is less complicated and needs less technical requirements in comparison with one beforehand depicted by Di Pinto et al. (2005) and Hossain et al. (2017). The PCR products showed a high specificity of the PCR approach in connection to the outcomes acquired by Di Pinto et al. (2005).

In this work, target DNA was effectively distinguished for each species where intensification was not influenced by spice addition or the cooking procedure as appeared in the sausage samples results (Figures 8,9) where comparative outcomes were found in fermented sausages (Kesmen et al., 2006).

We tried to distinguish donkey from horse meat since they are nearly associated species and have a high review of sequence homology. However, in this work, no cross-reaction was observed and species-specific PCR products of donkey and horse separated by agarose gel electrophoresis permit perfect species identification (Figures 2, 3).

However this study has exceptionally dedication and identification reach to 1:10000 (0.01\%) of donkey or horse tissue in beef meat. This was superior to that of Kesmen et al. (2007) who detailed a recognition limit of $0.1 \%$ foreign meat in the sausage samples for porcine, horse and donkey DNA. This was parallel to that of Matsunaga et al. (1999) who confirmed a recognition limit of $0.25 \mathrm{ng}$ of DNA utilizing a multiplex PCR procedure of the mitochondrial cytochrome $b$ gene from six species and 5 ng of DNA using PCR-RFLP-DHPLC analysis on the mitochondrial COI gene as reported by Song et al. (2016).

Testing 96 meat and meat product samples which had been gathered arbitrarily from road sellers and mainstream retail markets of Giza governorate (24 of burger, 16 of minced meat, 24 of kofta, 16 of sausage, 7 of raw meat and 9 of launcheon) uncovered $18.75 \%$ from sausage, $12.5 \%$ from minced meat and $4.16 \%$ from kofta for donkey and $12.5 \%$ for sausage from horse. This is higher than that of Zahran \& Hagag (2015) where they reported that $5 \%, 3 \%$ and $4 \%$ of minced meat samples were contaminated with donkey, goat and sheep meat, respectively, Moreover, $6 \%, 4 \%$ and $4 \%$ of sausage samples were contaminated with donkey, goat and sheep meat, respectively, in reverse to what was marked., On contrary, this was lower than that of Mousa et al. (2017) who revealed that the incidence of adulteration in luncheon, hot dog, sausage and minced meat with horse meat were $24 \%, 8 \%, 64 \%$ and $56 \%$, respectively in Alexandria city of Egypt.

Adulteration with donkey and horse meat, in the past, had been reported by few specialists in Egypt (El-Shewy, 2007; Abd El-Nasser et al., 2010; Jaayid, 2013; Mousa et al., 2017). However contamination rate with donkey meat in our investigation is higher than that detailed in Assuit governorate in Egypt by Abd El-Nasser et al. (2010) in minced meat (7\%) and sausage (8\%); this might be ascribed to our stress on the street vendors where there is a powerless control on food. In Egypt, equines are not a legitimately utilized for human feeding. Its presence affirms adulteration for profit drive point and thus gives a thought that meat has been handled under unhygienic environments constituting conceivable hazard to human health.

\section{Conclusions}

The systems applied in this study provide delicate recognition of donkey and horse tissue in beef meat and meat products without any need to add RFLP or sequencing. The streamlined strategy speaks to a legitimate PCR based technique to distinguish equine meat contaminations in fresh and processed beef meat products for quick, precise outcomes. Moreover, use of species-specific PCR does not need expensive devices such as real-time PCR analyses. Finally, this work also highlights on aggravation of the meat adulteration problem in Egypt.

\section{Acknowledgements}

This work was supported by a grant (11020304) from the National Research Center (NRC) in Egypt.

\section{References}

Abbas, O., Zadravec, M., Baeten, V., Mikuš, T., Lešić, T., Vulić, A., Prpić, J., Jemeršić, L., \& Pleadin, J. (2018). Analytical methods used for the authentication of food of animal origin. Food Chemistry, 246, 6-17. http://dx.doi.org/10.1016/j.foodchem.2017.11.007. PMid:29291879.

Abd EL-Nasser, M., Labieb, H. Y., \& Abd El-Aziz, D. M. (2010). Identification of meat species in some meat products in Assuit city. Assiut University Bulletin for Environmental Researches, 13(2), 1-13.

Ballin, N. Z. (2010). Authentication of meat and meat products. Meat Science, 86(3), 577-587. http://dx.doi.org/10.1016/j.meatsci.2010.06.001. PMid:20685045.

Ballin, N. Z., Vogensen, F. K., \& Karlsson, A. H. (2009). Species determination - can we detect and quantify meat adulteration? Meat Science, 83(2), 165-174. http://dx.doi.org/10.1016/j.meatsci.2009.06.003. PMid:20416768.

Callao, M. P., \& Ruisanchez, I. R. (2018). An overview of multivariate qualitative methods for food fraud detection. Food Control, 86, 283293. http://dx.doi.org/10.1016/j.foodcont.2017.11.034.

Chen, S. Y., Liu, Y. P., \& Yao, Y. G. (2010). Species authentication of commercial beef jerky based on PCR-RFLP analysis of the 
mitochondrial $12 \mathrm{~S}$ rRNA gene. Journal of Genetics and Genomics, 37(11), 763-769. http://dx.doi.org/10.1016/S1673-8527(09)60093-X. PMid:21115170.

Di Pinto, A., Forte, V. T., Conversano, M. C., \& Tantillo, G. M. (2005). Duplex polymerase chain reaction for detection of pork meat in horse meat fresh sausages from Italian retail sources. Food Control, 16(5), 391-394. http://dx.doi.org/10.1016/j.foodcont.2004.04.004.

Doosti, A., Ghasemi Dehkordi, P., \& Rahimi, E. (2014). Molecular assay to fraud identification of meat products. Journal of Food Science and Technology, 51(1), 148-152. http://dx.doi.org/10.1007/s13197-0110456-3. PMid:24426061.

El-Shewy, E. A. (2007). Identification of meat species in some "Ready to eat" meat products sold in Egyptian markets. Zagazig Veterinary Journal, 35(2), 10-18.

Flores-Munguia, M. E., Bermudez-Almada, M. C., \& Vazquez-moreno, L. (2000). Detection of adulteration in processed traditional meat products. Journal of Muscle Foods, 11(4), 319-332. http://dx.doi. org/10.1111/j.1745-4573.2000.tb00435.x.

Hossain, M. A. M., Ali, M. E., Hamid, S. B. A., Asing, Mustafa, S., Desa, M. N. M., \& Zaidul, I. S. M. (2017). Targeting double genes in multiplex PCR for discriminating bovine, buffalo and porcine materials in food chain. Food Control, 73, 175-184. http://dx.doi. org/10.1016/j.foodcont.2016.08.008.

Ilhak, O. I., \& Arslan, A. (2007). Identification of Meat Species by Polymerase Chain Reaction (PCR) Technique. Turkish Journal of Veterinary and Animal Sciences, 31(3), 159-163. Retrieved from pdfs. semanticscholar.org/dfca/fd6d328700e2efe9932395438f6d00182777.pdf

Jaayid, T. A. (2013). Rapid and sensitive identification of horse and donkey meat in Iraqi Markets Using SSR and PCR-RFLP based on mitochondrial DNA cytochrome B gene. Journal of Agricultural Science and Technology A, 3(11), 896-903. Retrieved from https://www. researchgate.net/profile/Mohammed_Ali190/publication/318967003_ Volume_3_Number_11A2013/data/5988775e0f7e9b6c8539b3cb/ Volume-3-Number-11A-2013.pdf

Karlsson, A. O., \& Holmlund, G. (2007). Identification of mammal species using species-specific DNA pyrosequencing. Forensic Science International, 173(1), 16-20. http://dx.doi.org/10.1016/j. forsciint.2007.01.019. PMid:17331687.

Kesmen, Z., Sahin, F., \& Yetim, H. (2007). PCR assay for the identification of animal species in cooked sausages. Meat Science, 77(4), 649-653. http://dx.doi.org/10.1016/j.meatsci.2007.05.018. PMid:22061954.

Kesmen, Z., Yetim, H., \& Sahin, F. (2006). PCR assay for the identification of animal species in Turkish fermented sausages. In Proceedings of the 1st Egyptian-Jordanian conference on biotechnology and sustainable development: current status and future scenarios (pp. 151-155). Cairo: NCR.

Kesmen, Z., Yetim, H., \& Şahin, F. (2010). Identification of different meat species used in sucuk production by PCR assay. Gida, 35, 8187. Retrieved from http:// citeseerx. ist.psu. edu/ viewdoc/downlo ad?doi=10.1.1.531.2043\&rep=rep1\&type $=$ pdf

Lenstra, J. A. (2003). DNA methods for identifying plant and animal species in food. In M. Lees (Ed.), Food authenticity and traceability (pp. 34-36). Florida: CRC Press.

Lockley, A. K., \& Bardsley, R. G. (2000). DNA-based methods for food authentication. Trends in Food Science \& Technology, 11(2), 67-77. http://dx.doi.org/10.1016/S0924-2244(00)00049-2.
Lopez-Andreo, M., Lugo, L., Garrido-Pertierra, A., Prieto, M. I., \& Puyet, A. (2005). Identification and quantitation of species in complex DNA mixtures by real-time polymerase chain reaction. Analytical Biochemistry, 339(1), 73-82. http://dx.doi.org/10.1016/j. ab.2004.11.045. PMid:15766713.

Man, C. Y. B., Aida, A. A., Raha, A. R., \& Son, R. (2007). Identification of pork derivatives in food products by species-specific polymerase chain reaction (PCR) for halal verification. Food Control, 18(7), 885-889. https://doi.org/10.1016/j.foodcont.2006.05.004.

Matsunaga, T., Chikuni, K., Tanabe, R., Muroya, S., Shibata, K., Yamada, J., \& Shinmura, Y. (1999). A quick and simple method for the identification of meat species and meat products by PCR assay. Meat Science, 51(2), 143-148. http://dx.doi.org/10.1016/S03091740(98)00112-0. PMid:22061698.

Meira, L., Costa, J., Villa, C., Ramos, F., Oliveira, M. B. P. P., \& Mafra, I. (2017). EvaGreen real-time PCR to determine horse meat adulteration in processed foods. Lebensmittel-Wissenschaft + Technologie, 75, 408-416. http://dx.doi.org/10.1016/j.lwt.2016.08.061.

Mousa, M., Nashwa, N., Helmy, M., \& Nasser, M. (2017). Biotechnological uses in assessment of some meat products adulteration with equine meat. Alexandria Journal of Veterinary Sciences, 54(2), 52-57. http:// dx.doi.org/10.5455/ajvs.252393.

Nakyinsige, K., Man, Y. B., \& Sazili, A. Q. (2012). Halal authenticity issues in meat and meat products. Meat Science, 91(3), 207-214. http://dx.doi.org/10.1016/j.meatsci.2012.02.015. PMid:22405913.

Rahmati, S., Julkapli, N. M., Yehye, W. A., \& Basirun, W. J. (2016). Identification of meat origin in food products- a review. Food Control, 68, 379-390. http://dx.doi.org/10.1016/j.foodcont.2016.04.013.

Shears, P. (2010). Food fraud - a current issue but an old problem. British Food Journal, 112(2), 198-213. http://dx.doi. org/10.1108/00070701011018879.

Singh, V. P., \& Neelam, S. (2011). Meat species specifications to ensure the quality of meat: a review. International Journal of Meat Science, 1(1), 15-26. http://dx.doi.org/10.3923/ijmeat.2011.15.26.

Song, L., Jiang, J., Mao, T., Shi, N., Li, W., Hao, J., Hu, Z., \& Guo, M. (2016). Identification of pork (susscrofa), horse (Equuscaballus) and donkey (Equusasinus) by PCR-RFLP-DHPLC analysis on the mitochondrial COI gene. IOSR Journal of Biotechnology and Biochemistry, 2(7), 98-103.

Vandendriessche, F. (2008). Meat products in the past, today and in the future. Meat Science, 78(1-2), 104-113. http://dx.doi.org/10.1016/j. meatsci.2007.10.003. PMid:22062100.

Wielogorska, E., Chevallier, O., Black, C., Galvin-King, P., Delêtre, M., Kelleher, C. T., Haughey, S. A., \& Elliott, C. T. (2018). Development of a comprehensive analytical platform for the detection and quantitation of food fraud using a biomarker approach. The oregano adulteration case study. Food Chemistry, 239, 32-39. http://dx.doi. org/10.1016/j.foodchem.2017.06.083. PMid:28873575.

Xiang, W., Shang, Y., Wang, Q., Xu, Y., Zhu, P., Huang, K., \& Xu, W. (2017). Identification of a chicken (Gallus gallus) endogenous reference gene (Actb) and its application in meat adulteration. Food Chemistry, 234, 472-478. http://dx.doi.org/10.1016/j.foodchem.2017.05.038. PMid:28551263.

Zahran, D., \& Hagag, S. (2015). Use of molecular biology techniques in the detection of fraud meat in the Egyptian market. African Journal of Biotechnology, 14(5), 360-364. http://dx.doi.org/10.5897/ AJB2014.14297. 